\title{
233. Thrombo-hämorrhagisches Syndrom bei der Verbrennungskrankheit
}

\author{
H. Borgolte* und M. Dohmen-Bonn
}

Thrombo-Haemorrhagic Complications in Burn Injuries

Summary. Of 53 patients treated for burns at the Surgical University Clinie, Bonn, from 1967 to 1970 , in 33 patients, special surveillance of the coagulation physiology was carried out and 21 received heparin as prophylaxis.

Out of this group of 33 patients whose coagulation processes were closely watched, 14 showed an increased turnover of coagulation factors or a reactive fibrinolysis.

The thrombo-haemorrhagic syndrome could not be prevented by heparin in all the cases.

It was shown that the increased turnover of coagulation factors took place only in the first week, while the reactive fibrinolysis occurred only during the third week of treatment.

A correlation between the changes in the coagulation processes and the extent and degree of severity of the burns could not be established, due to the small number of patients studied.

Zusammenfassung. Von 53 in der Chirurgischen Universitätsklinik in Bonn behandelten Patienten mit Verbrennungskrankheit in den Jahren 1967 bis 1970 wurden 33 Patienten gerinnungsphysiologisch überwacht und 21 Patienten prophylaktisch heparinisiert.

Aus diesem Kollektiv von 33 gerinnungsphysiologisch überwachten Patienten zeigten 14 einen gesteigerten Umsatz von Gerinnungsfaktoren oder eine reaktive Fibrinolyse.

Das thrombo-hämorrhagische Syndrom konnte durch Gaben von Heparin nicht in allen Fällen verhindert werden.

Es zeigte sich, daß eine Umsatzsteigerung von Gerinnungsfaktoren nur in der ersten Behandlungswoche, eine reaktive Fibrinolyse ausschließlich nach der dritten Behandlungswoche auftrat.

Eine Korrelation zwischen Änderungen im Gerinnungssystem, Ausdehnung und Grad der Verbrennung konnte bei der geringen Patientenzahl nicht gefunden werden.

\section{4. Örtliche Behandlung frischer Verbrennungen}

\section{P. R. Zellner-Ludwigshafen}

\section{Local Treatment of Recent Burns}

Summary. The local treatment of burns includes the control of infection and the surgical care of the burns. The treatment of infection on the body surface, instituted after the shock-phase is over, has in the past few years led to a statistically-proven lowering of the mortality rate due to septicaemia, which was so feared in the past, thanks to the introduction of potent therapeutic agents acting on the body surface and intensive care with the aid of modern technical equipment. But even though fighting the infection is important, the restoration of the skin cover 